UDC 330.341.1: 502.34

DOI: $10.15587 / 2312-8372.2018 .135484$

\section{Kharenko D., Dyshkantiuk 0., Salamatina 5., Kovalenko L.}

\title{
RESEARCH OF THE GASTRONOMIC BRAND OF TOURIST DESTINATION
}

У всьому світі зростає конкуренція серед туристичних дестинацій, які активно впроваджують інноваиійні технологї просування. Формування конкурентоспроможнього гастрономічного бренду є ефективною стратегією в боротьбі за міжнародні ринки, забезпечуючи стабільний туристичний потік і економічний розвиток регіону.

Дана робота була спрямована на дослідження процесу формування гастрономічного бренду для посилення привабливості туристичної дестинації. Вивчалися особливості формування регіонального гастрономічного бренду мультикультурної туристичної дестиначії на прикладі міста Одеси (Україна).

Одним з найбільи проблемних місиь формування гастрономічного бренду Одеси є недостатня взаємодія його основних складових. У цьому процесі взаємодї повинні брати участь всі зацікавлені сторони і учасники ринку. Крім того, ще не розроблена ефективна стратегія для формування регіонального гастрономічного бренду. Необхідно визначити основних учасників гастрономічного життя міста, їх роль у формуванні бренду і виробити стратегію взаємовигідного розвитку. В результаті застосування методів контент-аналізу та експертного інтерв'ювання був зроблений висновок про великий нереалізований потенціал гастрономічного бренду Одеси як на міжнародному, так і на національному рівні. У тому числі було виявлено, що ресторанний бізнес і гастрономічні фестивалі є вкрай важливими елементами у формуванні гастрономічного бренду, будучи джерелом гастрономічної культури. Були виявлені ключові проблеми, пов'язані з формуванням гастрономічного бренду міста. для їх рішення було висунуто ідею зі створення гастрономічних карт-путівників Одеси, які проінформують туристів і жителів міста про гастрономічне життя регіону. Дані інформаційні системи дозволять усім учасникам ринку ефективно взаємодіяти між собою, активізувати розвиток бізнесу та сформувати туристичні кластери. Також були запропоновано шляхи формування бренду на основі культурних і кулінарних традицій регіону.

Практична цінність проведеного аналізу, полягає в тому, що воно може служити базою для подальших досліджень і сформувати ефективну стратегію просування Одеси як туристичної дестинації.

Ключові слова: гастрономічний бренд, гастрономічний туризм, формування бренду дестинацій, туристична дестинащії, гастрономічні карти.

\section{Introduction}

Positioning and promotion is an important stage of development for any territory, because the formation of attractiveness factors for different target groups is a serious competitive advantage in the struggle of the territories.

The search for effective tools and methods comes first in importance in the process of forming and promoting the brand of the territory. The most important components of the tourist brand of the region are: the richness of the history of the place, the presence of an attractive cultural heritage, interesting cultural events, vivid personalities who lived or live in the area and others. But a significant place belongs to the gastronomic component, as well as the structure, content and characteristics of the gastronomic industry. It is the gastronomic component of the tourist product that is the most important factor shaping the tourist image of the destination in the conditions of the economy of impressions [1, 2].

By now, the features of Ukrainian gastronomic branding have not been sufficiently studied. In this research, approaches are being developed to determine the specifics of the formation of gastronomic brands of multicultural cities by the example of the city of Odesa (Ukraine).

Identification of the cuisine of the country in general and the cuisine of the city is a mistake, because in this case the city is deprived in the conditions of the above mentioned acute competition of cities of a significant competitive advantage - the gastronomic component of the territorial brand, the culinary uniqueness and attractiveness of the city. On the other hand, the very cosmopolitan nature of the city creates a threat: the coexistence of different cultures can deprive the city of its own, unique gastronomic culture, culinary exclusiveness.

Therefore, it is relevant to study the gastronomic branding of the city of Odesa as a promising tourist destination.

\section{The object of research and its technological audit}

The object of the research is the gastronomic brand of Odesa as a tourist destination.

When forming a gastronomic brand, multicultural cities, such as Odesa, face certain difficulties. On the one hand, most often such cities differ in many respects from the rest of the country, including customs, mentality, traditions. The sphere of gastronomy of these cities also stands apart, the national and urban culinary customs are very different from each other.

In conditions of multiculturalism, it makes sense to choose a special way of building a gastronomic brand of 
the city - to form a brand not on the basis of gastronomic achievements, but on the basis of myths, the history of the city, its cultural characteristics, traditions.

\section{The aim and objectives of research}

The aim of research is analysis of the peculiarities of the formation of the gastronomic brand of Odesa as a multicultural city with the purpose of developing a proposal for enhancing tourist attractiveness.

This aim necessitates the solution of problems:

1. To identify the difficulties in creating and promoting the gastronomic brand of Odesa.

2. To identify the main components of the gastronomic brand of Odesa and develop practical recommendations for its construction.

\section{Research of existing solutions of the problem}

Researchers [3-6] note a number of deep links between gastronomy and tourism. Local cuisine is a powerful tool for the struggle for the consumer in the tourism services market, a significant resource of the territory, its competitive advantage, an important component of the brand of the city, region, country [7-10]. The gastronomic factor is a significant part of the tourist product. Researchers define gastronomy not just as an important component of a tourist trip, but as a key motif of travel. Local cuisine is an important part of the brand of the territory, not only for gourmets, but for another, more numerous segments of tourists - the group that is interested in finding authenticity, understanding the identity of the territory.

The search for authenticity has become a popular travel motive [11], and gastronomy is a significant source of identity formation of territory, an important marker of tourist destinations, contributes to the creation of a «sense of place» $[12,13]$. After all, national food is a way of learning the culture of the territory, an interesting, interactive, playful way to get to know your destination. Gastronomy reflects the nature and mentality of the local population [14]: it absorbs myths, tales, local history, traditions, religious characteristics, relationships in families, etc. It is not surprising that gastronomy is referred to intangible cultural heritage, for example, UNESCO included Mexican cuisine, Mediterranean diet, France cuisine in the list of intangible cultural heritage [15]. Cuisine, as a cultural heritage, allows to get a unique tourist experience [16].

It is obviously, there is a specific character of the formation of gastronomic brands in rural areas, «Monogastronomic» cities and cosmopolitan, multicultural cities. In the first case, the main emphasis is usually made on the production of local unique agricultural products. Rural areas can be the birthplace of unique dishes, locals can be the custodians of technology and gastronomic cooking secrets [17]. The second type of territory - the city with a pronounced gastronomic image, often boils down to a limited range of dishes, products, institutions. For example, such «city of one product» in Ukraine can be called Poltava (dish - Poltava varenyky). From other examples of monobrand cities, it is possible to recall Parma and Parma ham. There are territories in which branding of food and alcohol products that are most popular among tourists is of an international character, does not have regional specificities (Ukrainian salo, Scotch whiskey). The third type of territory includes large «cosmopolitan» cities, where many traditions and cultures are connected. A unique synthesis of cultures is reflected in the gastronomic history of the city - different recipes, customs, ways of cooking, serving, serving dishes or neighbors in the cuisine of such cities [18, 19]. Bright examples of such cities can be called the major Ukrainian cities Kyiv, Kharkiv, Lviv and of course Odesa.

As the most famous and traditional methods of marketing and branding are the development of visual symbols of the region or city, the promotion of the territory at the expense of iconic figures such as historical figures, politicians, artists. However, now the most effective trend in the formation of the brand of the territory is the cultivation and socialization of city brands, thanks to which the governments of countries and cities pay more attention to communicative and cultural capital. In this regard, emphasis is placed on creative industries that help in uncovering the cultural potential of the territory, and as part of this concept, gastronomy is increasingly used as an attraction and a tool for territorial branding.

Also, the results of the literary analysis allow to conclude that the gastronomic component is very important for the development of tourism and the destination brand. It is necessary to analyze and form the gastronomic brand of the destination, taking into account the specifics and peculiarities of the territory.

\section{Methods of research}

It is decided to resort to quality research methods. This choice is justified by the fact that qualitative research is aimed at a few groups of respondents. This allows to interview experts in the field of restaurant business, tourism and advertising, and thereby gain a deeper analysis of a topic that has been little studied, such as the gastronomic brand of Odesa.

The main essence of qualitative research is their focus on obtaining a greater degree of qualitative information than quantitative. «Qualitative» information implies more detailed information about the subject of research, based on the explanation and interpretation of empirical data. Due to the fact that the topic has been little studied, and the collection of information is complicated by the fact that the target audience is outside the recreation area, the qualitative research method is the most reasonable method.

These circumstances make it unnecessary and impossible to conduct a quantitative study, in this regard, the choice of the participant fell on the methods of qualitative research. At this stage, one should rely on the opinion of specialists who are directly related to the specific situation (restaurant business, work with tourists, development of brand strategies), have sufficient experience in this area and can develop a generalized situation and have their own expert opinion on this issue.

It is important to note that tourism in modern society is increasingly perceived as a service sector, but rather related to the industry of impressions. Destinations as a system aim to create a variety of impressions among tourists. A qualitative research method makes it possible to study this experience and impressions, since it is aimed at studying the nature of the object and does not place restrictions on the subject under study. 
In the framework of this research, the authors select the expert interview method. The selected deep semi-structured style of the interview, since in this case it is possible, based on the data heard, to obtain more in-depth information from the respondent. In the context of this interview, it is possible to use certain information as a reference, and also to connect the data obtained during the research. A list of certain questions is developed in the format of a guide interview. In the process of interviewing, sound recording devices are used. This will allow to concentrate on the respondent and its speech, as well as gives an opportunity to write down all the information in detail.

As experts for the interview, three categories of specialists are selected:

- representatives of the restaurant business associated with the brand of Odesa and are engaged in the popularization of gastronomy (owners and directors of restaurants that are aimed at attracting both locals and tourists);

- persons associated with marketing activities, representatives of advertising agencies;

- representatives of travel companies that offer tours around Odesa and are engaged in the reception of both Ukrainian and foreign citizens.

The main criterion for choosing experts is their competence and authority. Consequently, the number of specialists in each group of respondents is estimated not quantitatively, but qualitatively.

Within the framework of the work, 35 experts were interviewed. It is important to note that most specialists carry out their activities on the border of two spheres, and experience is not limited only to their core activities.

The experts share their experience and opinion, which became the basis for the formation of a general picture of the situation associated with the gastronomic brand of Odesa and the development of recommendations for solving the main tasks that were formulated after processing the data. The analysis of the obtained data will be connected with an estimation of opinions of experts, consideration of their estimated judgment concerning research subjects as a whole and on each question of interview separately.

The guide interview consists of 12 questions of the main block, one additional for each group of respondents. An additional issue for representatives of travel agencies and restaurants is aimed at identifying features in the needs of tourists, and an additional issue for marketing and branding specialists is aimed at getting recommendations on how to measure the effectiveness of the brand strategy.

The subject of research is the degree of influence of the gastronomic factor on the tourist attractiveness of the city, strengths and weaknesses in the development of the gastronomic brand of the city.

However, in the framework of this research, it is not enough to conduct interviews, and to get more data, the content analysis method is chosen. For this method, the most popular international tourist Internet platforms are selected, including websites of travel agencies that offer tours to Odesa. The content analysis is aimed at these resources in order to reveal the number of references to «Odesa» and restaurants of the city.

\section{Research results}

6.1. Content analysis results. The study of the formation of the gastronomic brand of Odesa began with the content analysis of international tourist Internet platforms. First of all, the TripAdvisor platform and the content analysis of the Booking.com site were studied.

As a result of content analysis of tourist Internet platforms and travel agency websites, it is possible to be sure that there is no gastronomic brand in the city. Most tourists go to Odesa for the sake of attractions and recreation on the Black Sea, but there is a tendency among tourists to visit the bars and clubs of the city in order to explore the nightlife of Odesa. It is important to note that the lack of a large number of reviews (especially among foreign tourists) associated with restaurants and the Odesa gastronomic brand is due to the fact that the gastronomic culture of Odesa is only developing and the world community is just starting to get acquainted with it. Including, the interest of tourists in the gastronomic component of the city would be higher if the travel agencies more actively offered gastronomic tours with a unique «Odesa color».

6.2. General analysis of interviews with experts. In connection with the lack of a gastronomic brand, it is important to understand how to shape and evaluate the role of restaurants and gastronomic festivals in this process. For more information and recommendations, interviewing experts selected during the study was divided into three groups and related their opinions on the gastronomic brand and the role of restaurants in its formation. Experts note that the restaurant business in the city of Odesa has received sufficient development, there are many enterprises of different levels, and however, not always the quality of food and service in these enterprises are at the proper level. So, according to experts, food companies are still not too focused on tourists, there are not enough menus in different languages, attendants, speaks foreign languages, individualized services, which foreign tourists are expecting, who come to Odesa. Often the cuisine quality and the service is much lower than the expectations of tourists.

Almost all experts said that at present there is no such gastronomic brand of Odesa. In Odesa, in many areas, including in gastronomy, they tried to do everything «in a foreign manner», absorb European traditions and follow Western taste. This trend has negatively affected the process of forming its own gastronomic image of the city.

Evaluating the role of food enterprises in the existing tourist product of Odesa, experts have given these enterprises one of the main roles in shaping the tourist image of the city. Meals in the economy of impressions are one of the key links in creating positive memories of staying in the city - restaurants and cafes are the basis for creating a gastronomic brand of the city. These institutions will allow tourists to have a wonderful memory of the city.

6.3. Difficulties in creating and promoting the gastronomic brand of Odesa. Among the difficulties in creating and promoting the gastronomic brand of Odesa, experts pointed to the following reasons.

First, the lack of individuality in most catering enterprises in the city of Odesa. This trend exists as a consequence of the desire of entrepreneurs to cut costs and get high profits. Secondly, the lack of «Odesa» chefs, who know and love their national (Ukrainian) and Odesa cuisine.

It is extremely important that in the brand-name Odesa restaurant worked a local chef who knows the history of the city, local recipes, customs, ready to restore and cook in the old Odesa recipes. 
Thirdly, there are a lot of bureaucratic barriers and imperfections in the legislation that hamper the development of the restaurant business. The entrance barrier to the industry is extremely high. But even if it is possible to open a restaurant, its further work is complicated by a large number of complexities

6.4. Identification of components of the gastronomic brand of Odesa. In the course of the expert survey conducted by the authors, three components of the gastronomic brand were formulated, they can create an attractiveness of the city within the framework of various types of tourism. General principles of forming the components of the gastronomic brand of Odesa - culture, history, traditions of the territory as a basis, the starting point for creating components of the gastronomic brand.

The first component is «cuisine of the old Odesa». A significant component of the main tourist brand of the city is the idea of it as the Southern Palmyra of a huge empire (XVIII - early XX century) and a multinational city where Ukrainians, Russians, Greeks, Italians, French people lived and worked. The European spirit defines in Odesa: its town-planning structure; architectural ensembles; collection of art. The use of European themes in the formation of the gastronomic brand will, on the one hand, support, strengthen the already existing cultural brand of the city, on the other hand, create a new interesting image of Odesa for tourists.

The second component of the gastronomic brand is the originality of Odesa as the basis for creative space. A significant trend in the restaurant business was the growing popularity of creative institutions, which main value is the creative atmosphere, creating a place for creative activity of visitors, meetings of people close to the spirit, creative class.

Creative space, as it is known, this is not an invention of the late XX century. There are examples in world history (for example, in Paris there are such creative cafes as Le Procope (visitors to Voltaire, Hugo, Balzac), La Rotonde (Picasso, Modigliani) .The branding of a catering establishment should be based on parallels between modern the creative spaces-cafes and historical creative cafes of the borders of the centuries. Let's note, in Odesa cultural and tourist clusters («Bandit Odesa», «Industrialists», «Bohemia») were actively formed, creative cafes, developing traditions of the former ones such as the Fanconi cafe and the Gambrinus beer pub, were also present in Odesa.

The basic principles of branding «Odesa Cafe»:

- styling dishes in the spirit of the era should be com-

plemented by the creation of an atmosphere;

- creative program should become an indispensable

element of visiting such restaurant;

- creation of a creative atmosphere that allows tourists not only to become spectators of the performance in the spirit of the era, but to plunge into the process of co-creation.

The third component is «Odesa - gastronomic center of Ukraine». In multinational Ukraine there are a large number of ethnic cuisines. It often happens that a tourist visits only Ukraine in Kiev, but it would be interesting for such tourist to make any idea of the whole country. An important way to get to know the local culture is to get to know the local cuisine. The authors propose to create a gastronomic parade, an exhibition, a showcase of the cuisines of the peoples of Ukraine. It is known that in Odesa there are 134 of 134 nationalities living in Ukraine. Such «ethnic portfolio» will emphasize the role of Odesa as the representative of the whole country, the gate in Ukraine. The formation of this component is natural, because Odesa was historically conceived as a city that connects many cultures and traditions (PortoFranco, the sea gates of the Empire, etc.).

Creation of such culinary variety will allow the tourist, visits only Odesa, make an idea of Ukraine, stimulate it to visit other regions of the country, that is, serve as a way to promote regional brands of territories. In the ethnic portfolio can be included various cuisines, for example Cossack, Western, Bulgarian, Romanian, Moldovan, etc.

Principles of forming the component «Odesa is Gastronomic Gate of Ukraine»:

- formation of the concepts of institutions that allow the tourist to get acquainted not only with authentic cuisines of the peoples of Ukraine, typical dishes, ways of consuming them, but also with their customs and art; - tourist should be able to get not only gastronomic, but also cultural experience;

- concept of institutions should include familiarity with local traditions, songs, beliefs, crafts.

6.5. The main conclusions and practical recommendations for building a strategy for the gastronomic brand of Odesa. The result of content analysis and expert interview is the confirmation of the idea that the gastronomic brand of Odesa at the moment does not exist. In particular, experts emphasize the importance of gastronomy in the formation of the tourist brand of Odesa, saying that gastronomic culture makes it possible to understand the atmosphere of Odesa, to get more impressions and emotions. Among them there are several basic ideas and judgments, which are adhered to by almost all experts. First, in Odesa there are many directions for development of the gastronomic brand: the Tsarist era, the USSR, literary classics, the marginal atmosphere, the bar industry, etc. Secondly, the concept of «Odesa cuisine» is almost absent, therefore it is better to put the city's gastronomic brand the atmosphere that best conveys and describes the gastronomic culture. And thirdly, the formation of a gastronomic brand should begin with the establishment of an association of restaurants to show the tourist the whole range of gastronomic characteristics of the city.

Interviewing experts has made it possible to identify several reasons why the formation of a gastronomic brand is complicated and the influence of restaurants on the city's brand is weak:

- insufficiently qualified personnel with necessary experience:

- problems with access to fresh fruits and vegetables

12 months a year;

- underdevelopment of gastronomic culture in the subconscious of local residents and other difficulties.

Practical ways of solving these problems exist. First, it is necessary to popularize the profession of the cook. A few years ago this profession was considered the lot of losers. It is necessary to open culinary schools, hold master classes and hold festivals, where the chefs can show their professionalism, thereby increasing the prestige of the profession and declaring themselves not in the international arena. On the part of restaurateurs it is expected to provide all conditions for creativity and improve their own skills. 
Development of gastronomic culture takes place quite quickly. To raise interest in this area of life, festivals, competitions, prizes, and ratings should be held. People need to be told that going to a restaurant does not have to be timed to an important event, new formats of institutions are opened that are designed for different life situations. The public should be informed actively can make various media and social media.

The problem with the lack of a base for forming a gastronomic brand can be solved by focusing on the city's atmosphere, on those characteristics that describe the modern gastronomic image of Odesa: bars, live music, constant communication, bar culture, simple food.

Proceeding from all the analyzed data and experts' words, it can be concluded that the gastronomic life of Odesa is quite multifaceted and has many sections. In this connection, a scheme is developed for the most popular associations and topics related to Odesa and gastronomy (Fig. 1).

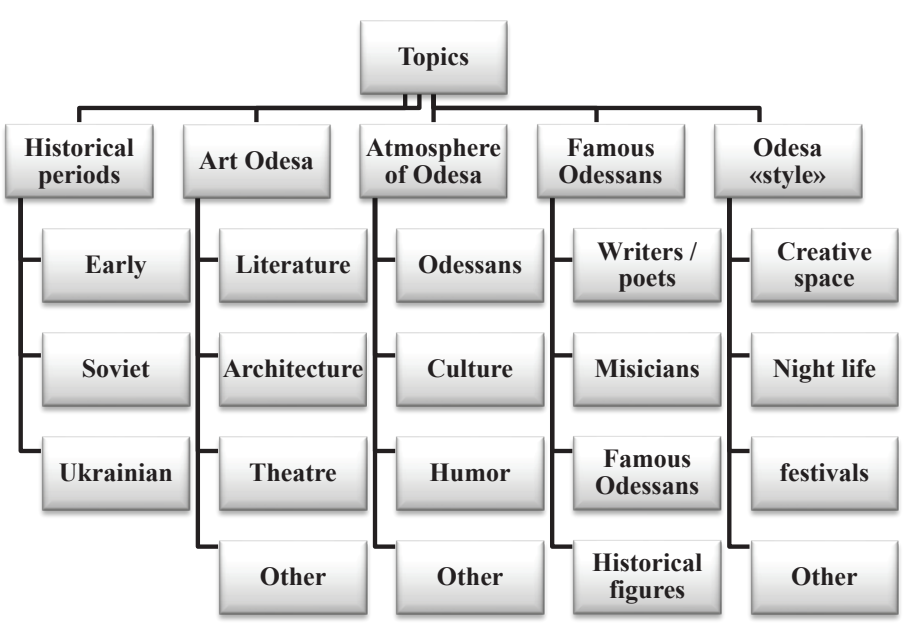

Fig. 1. Gastronomy topics in Odesa

This study shows that Odesa has a great potential for forming a gastronomic destination brand: cultural and historical heritage, various types of restaurants (according to concept, cuisine, average check), the desire of the participants of this market to form such brand. However, as already mentioned, the gastronomic brand does not exist and its formation can't be violent, the grain of gastronomy is laid and now it is necessary to wait for it to sprout and grow throughout the city. The only way to help develop the gastronomic brand of Odesa is information of the public about the existence of a gastronomic culture. In particular, it is noted that in most cases, the starting point is the restaurants, because they serve as a platform for the realization of ideas.

6.6. Development of special gastronomic guides for tourists. In the focus of this work, it is proposed to develop special gastronomic maps (guides) for tourists who could help in the orientation among catering establishments, and also introduce the city's gastronomic component to the city's guests. The map data can be presented both in hard copy, and as a website or as an application for a smartphone.

The perspective of this map is determined by the trend and the need to form information ecosystems. This ecosystem will allow all participants of the business process and consumers to interact. The need to create such system is due to the fact that most of the information people get now with the help of electronic devices, in particular travelers rely on applications and the Internet in the planning of the trip and the trip itself. The tourist ecosystem consists of many participants and niches, but due to the vastness of the niche of gastronomy, the need for creating a separate information ecosystem for it. The creation of such system will allow more effective interaction among all participants, both service providers and consumers.

At the moment there are no associations related to gastronomy, and here it's not about people's perceptions, but about organizational issues. Various associations, partnerships, commonwealths - all that helps market entities more effectively build their business processes that are absent in Odesa. In this regard, special attention should be paid to the formation of a gastronomic information system in order to establish not only the tourist flow, but also the work of the gastronomic sphere at the level of the whole city.

Based on these data, the idea appears to create gastronomic maps that will reflect all the slices of the gastronomic culture. These maps will be a gastronomic information ecosystem (Fig. 2), not only for tourists to help them choose places and get acquainted with the gastronomic culture of the city, but also for workers in this field as an assistant in organizing business processes.

Pointing out certain characteristics, using filters, a person will receive a route to restaurants that suit its needs and interests. This is promising, since there is no key topic related to the gastronomic brand of Odesa, so the tourist will have an opportunity to get acquainted with all the representatives of this sphere and get acquainted with most interesting Odesa cuisine.

Data of the maps will allow for a certain cost to make a tour of all establishments listed in the route. This amount will include a set of specific dishes in each institution that will reveal the gastronomic component of this place or route.

Including users of these maps will be able to book an excursion on this route. Within the framework of these excursions, it is supposed to tell the customer about the establishments themselves, as well as about the sights around.

First, it should be divided according to price criteria: a small, medium and high average check. Then it is possible to divide the restaurants according to the type of cuisine and the format. Including the location, both geographical and historical (building, street). This appendix will be a breakdown by topics that were mentioned earlier. When forming a map it is important to learn about the history of the place and help the tourist to plunge into the historical atmosphere of old Odesa. Do not forget about the purpose of visiting the institution breakfast, lunch, dinner or just to drink a cup of coffee.

The map data will allow to individually select a guide. For tourists that would like to get acquainted with the restaurants of high cuisine, with a high average score, a driver-guide will be offered, which will accompany the guests throughout the whole route, even if it is divided into several days. Gastronomic maps allow tourists to get acquainted not only with restaurants, cafes and bars, but also with markets that actively participate in the formation of the gastronomic brand of the city, whole streets and other gastronomic sights. 


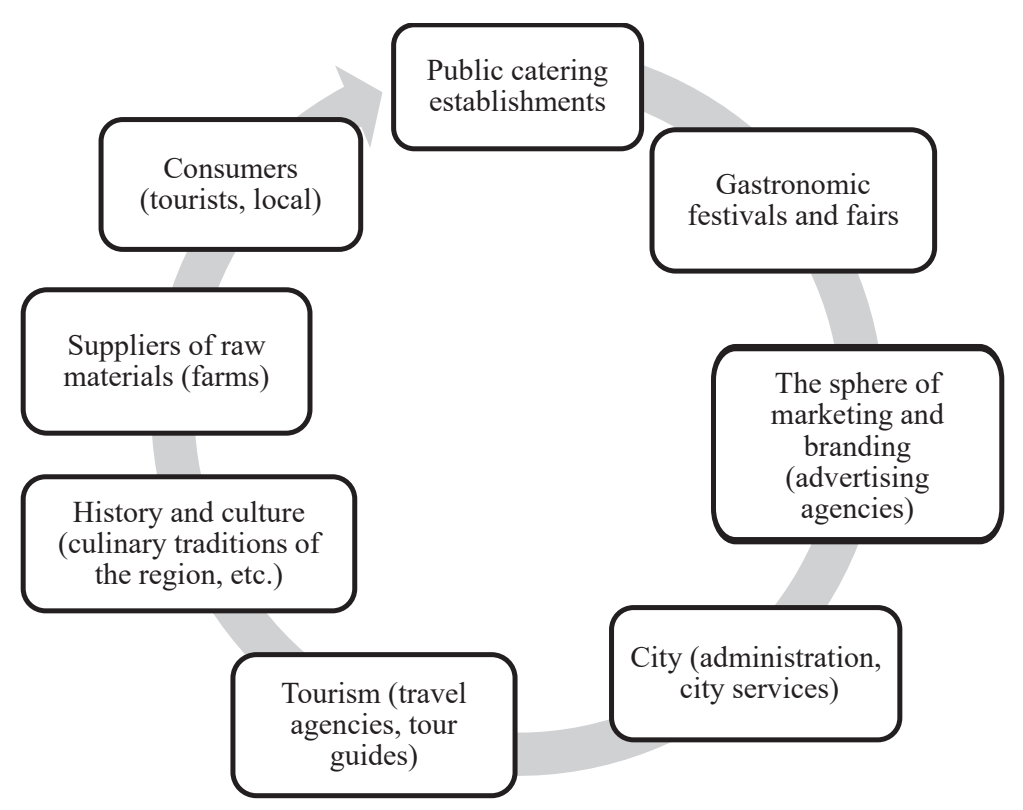

Fig. 2. Gastronomic information ecosystem in Odesa

The main aim that the author pursues by developing such maps is showing the tourist all the gastronomic sections of Odesa, to draw its attention to the extensive list of various restaurants that are ready to show him the unique atmosphere of Odesa. The presence of various routes will attract different target groups. Restaurants will create unique offers to draw attention to the routes where they are designated.

Including this program is aimed not only at tourists, but also at other participants of this market. Restaurateurs can unite for events: gastronomic quests and competitions, gastronomic dinners, the organization of lectures and festivals. The application should allow users to inform about new discoveries and measures, the newsline will be compiled using the best Internet portals.

The program «Gastronomic Maps» is a full-fledged information system designed for a large number of users. The main aim of this program is systematization of restaurants and cafes, helping restaurateurs and other market participants improve business processes, and show the city the whole variety of gastronomic life in Odesa.

\section{SWOT analysis of research results}

Strengths. The strengths of research object include:

- cultural, historical and recreational potential of the region;

- image of the tourist region and the history of the region;

- great gastronomic potential, multiculturalism and unique culinary traditions of the region;

- more than 1000 restaurants and cafes;

- museums and wine culture centers;

- quality food and a wealth of traditional cuisine;

- local people appreciate the gastronomic traditions of the region, participate in them in every possible way and like to visit local gastronomic festivals;

- unique events and gastronomic festivals;

- advantageous location in the resort area and natural and climatic conditions.
Weaknesses. The weaknesses of the research object are: - insufficient promotion of the region as a gastronomic brand;

- there is no cluster approach in development;

- insufficient interaction between stakeholders;

- program of gastronomic festivals requires improvement in order to be interesting, diverse and stimulate activity;

- ineffective marketing to promote local gastronomic events in other regions and abroad;

- poor-quality infrastructure (roads);

- geographical distance from tourist flows.

Opportunities. The perspective of the research object is that the Odesa region is the most promising gastronomic destination of Ukraine, which is located on the Black Sea coast, therefore it can be popular not only in Ukraine but also abroad. The potential of this destination can be developed by investments.

Threats. Threats to the research object include:

- competition from other gastronomic destinations (Lviv, Kyiv), which use innovative approaches for their promotion or provide other advantages (low price, investment, advantageous location, developed infrastructure, etc.); - unstable political and economic situation in Ukraine;

- lack of a systematic approach and corruption.

\section{Conclusions}

1. As a result of studying the city of Odesa, as a tourist destination, it is possible to unequivocally emphasize the urgent need to form a single brand of Odesa, which will help in attracting tourists. It will also increase its competitiveness relative to other major Ukrainian cities (Kyiv, Lviv). At the moment, the main focus is on the outdated image of Odesa, which attracts a limited segment of tourists. Therefore, it is concluded that it is advisable to resort to gastronomy as an instrument for promoting the tourist brand. Gastronomy can increase the attractiveness of this direction, both for young people and for the middle-aged audience. As a result of the application of methods of 
content analysis and expert interviewing, a conclusion is made about the absence of a gastronomic brand of Odesa. Including all experts it is confirmed that restaurants play an important role in the formation of such brand and for Odesa is a key source of gastronomic culture.

2. In the course of the practical study, data is collected that helps to identify key problems related to the formation of the gastronomic brand of the city and the development of restaurants in the key of this brand. To overcome these problems, an idea for the creation of gastronomic maps of Odesa is put forward in the framework of this research work. This will help to inform the public, including tourists, about all gastronomic segments of the city, thereby increasing the attractiveness of Odesa, as a crime. These maps are a gastronomic information ecosystem that will allow all market participants to communicate among themselves, improving the efficiency of business processes.

The practical importance of the work lies in the fact that the results of this research can serve as a basis for further studies of the gastronomic brand of the destination. And also serve as a solution to the problems of attracting restaurants in the formation of the gastronomic brand of Odesa.

\section{References}

1. Pine B. J., Gilmore J. H. Welcome to the experience economy // Harvard business review. 1998. Vol. 76, No. 4. P. 97-105.

2. Dyshkantiuk O. Economy Of Impressions - Current Stage Of Development Of Social Production // Ekonomika kharchovoi promyslovosti. 2016. Vol. 8, No. 4. P. 3-9.

3. Bessiere J. Local Development and Heritage: Traditional Food and Cuisine as Tourist Attractions in Rural Areas // Sociologia Ruralis. 1998. Vol. 38, No. 1. P. 21-34. doi: http://doi.org/ 10.1111/1467-9523.00061

4. Henderson J. C. Food tourism reviewed // British Food Journal. 2009. Vol. 111, No. 4. P. 317-326. doi: http://doi.org/ 10.1108/00070700910951470

5. Kivela J., Crotts J. C. Tourism and gastronomy: gastronomy's influence on how tourists experience a destination // Journal of Hospitality and Tourism Research. 2006. Vol. 30, No. 3. P. 354-377. doi: http://doi.org/10.1177/1096348006286797

6. Long L. M. Culinary tourism. Lexington: University Press of Kentucky, 2004.

7. Hjalager A. M. What do tourists eat and why? Towards a sociology of gastronomy and tourism // Tourism. 2004. Vol. 52, No. 2. P. $195-201$

8. Hjalager A., Richards G. Chapter 13 still undigested : research issues in tourism and gastronomy // Tourism and Gastronomy. 2002. No. 8. P. 224-234.
9. Richards G. Gastronomy: an essential ingredient in tourism production and consumption? // Tourism and Gastronomy. 2002. Vol. 11. P. 3-20.

10. Keller K. L. Strategic brand management. Harlow, 2008. 829 p.

11. Smith R. Authenticity: What Consumers Really Want by James H. Gilmore and B. Joseph Pine II // Journal of Product Innovation Management. 2009. Vol. 26, No. 3. P. 355-356. doi: http://doi.org/10.1111/j.1540-5885.2009.00663_1.x

12. Pine B. J., Gilmore J. H. The experience economy: work is theatre \& every business a stage. Cambridge: Harvard Business School Press, 1999. 252 p.

13. Scarpato R., Daniele R. New global cuisine: tourism, authenticity and sense of place in postmodern gastronomy // Food Tourism Around The World. 2003. P. 296-313. doi: http:// doi.org/10.1016/b978-0-7506-5503-3.50020-8

14. Getz D. Event studies: theory, research and policy for planned events. Taylor \& Francis, 2007. 476 p.

15. Getz D. Event tourism: Definition, evolution, and research // Tourism Management. 2008. Vol. 29, No. 3. P. 403-428. doi: http://doi.org/10.1016/j.tourman.2007.07.017

16. Brown D. C. Food in Global History // History: Reviews of New Books. 2000. Vol. 28, No. 2. P. 88-88. doi: http://doi.org/ 10.1080/03612759.2000.10525436

17. Kharenko D., Dyshkantiuk O., Ivychuk L. Analysis of gastronomic events: a case study of Portugal // Technology Audit and Production Reserves. 2017. Vol. 1, No. 5 (39). P. 79-85. doi: http://doi.org/10.15587/2312-8372.2018.124713

18. Daniela I. Interculturality - a factor of tourism development part 1 - gastronomy in tourism, attraction or impediment babaita carmen mihaela // Economy, business administration and economic statistics. 2003. No. 16. P. 23-28.

19. Dyshkantiuk O. et al. Gastronomy as an important element of the hospitality development // Economic and food security of Ukraine. 2017. Vol. 5, No. 3-4. P. 60-73.

Kharenko Dmytro, PhD, Senior Lecturer, Department of Hotel and Restaurant Business, Odessa National Academy of Food Technologies, Ukraine, e-mail: kharenko1980@gmail.com, ORCID: https:// orcid.org/0000-0001-7978-3287

Dyshkantiuk Oksana, PhD, Associate Professor, Department of Hotel and Restaurant Business, Odessa National Academy of Food Technologies, Ukraine, e-mail: dyshkantyuk.oksana@gmail.com, ORCID: https://orcid.org/0000-0001-9812-1916

Salamatina Svitlana, PhD, Associate Professor, Department of Hotel and Restaurant Business, Odessa National Academy of Food Technologies, Ukraine, e-mail: salamatina-svetlana@i.ua, ORCID: https://orcid.org/0000-0002-1584-2265

Kovalenko Liliia, Associate Professor, Department of Hotel and Restaurant Business, Odessa National Academy of Food Technologies, Ukraine, e-mail: ivychuklilia@gmail.com, ORCID: https:// orcid.org/0000-0002-1330-0702 